Article

\title{
A Case Study on Environmental Sustainability Assessment of Spatial Entities with Anthropogenic Activities: The National Park of Eastern Macedonia and Thrace, Greece
}

\author{
Despoina Aktsoglou * and Georgios Gaidajis \\ Laboratory of Environmental Management and Industrial Ecology, Department of Production Engineering and \\ Management, School of Engineering, Democritus University of Thrace, 67100 Xanthi, Greece; \\ geogai@pme.duth.gr \\ * Correspondence: daktsog@pme.duth.gr; Tel.: +30-25-4107-9356
}

Received: 22 February 2020; Accepted: 29 May 2020; Published: 1 June 2020

\begin{abstract}
The current paper presents a methodological framework that is able to evaluate the carrying capacity of protected areas where various human activities, apart from recreation and tourism, take place. The proposed framework converts the energy and product consumption into land required to satisfy those needs (Ecological Footprint) and compares them with the current land uses and available land (Biocapacity), in order to calculate carrying capacity. To facilitate the evaluation, an algorithm that calculates the Ecological Footprint, the Biocapacity, and the Carrying Capacity of the protected area under study by introducing 48 inputs was developed. The inputs were related to the evaluation of individual indicators assessing energy and product consumption of human activities such as households, tertiary sector, municipal buildings, public lighting, private and public transportation, and tourism. A new unit is introduced, the "equivalent person," since the anthropogenic activities within the boundaries of the protected area contribute in a dissimilar way to the total land requirements. The framework is applied, as case study, in the National Park of Eastern Macedonia and Thrace (NPEMT), Greece, with a view to validate and improve its applicability. Within the NPEMT, habitats of significant biodiversity and ecological value are in coexistence with extensive human activities (urban, rural, tourist, light industrial). The study area covers up to approximately 73,000 ha and its population is estimated at about 29,000 people. The Carrying Capacity of the NPEMT according to the current consumption patterns was estimated at 39,193 equivalent residents, which was higher than the current equivalent residents $(36,960)$, indicating a potential for tourism development at the NPEMT. The Ecological Footprint of the NPEMT was estimated at 181,324 Gha or $4.9 \mathrm{Gha} /$ pers $_{\mathrm{eq}}$, slightly higher than the European mean $\left(4.69 \mathrm{Gha} / \mathrm{pers}_{\mathrm{eq}}\right)$. Among activities, households and private transportation (with approximately $79 \%$ and $10 \%$, respectively), among land use, agriculture, livestock, and $\mathrm{CO}_{2}$ emissions (with approximately $36 \%, 30 \%$, and $30 \%$, respectively), and among products, beef, fruits/vegetables, and beverages (with approximately $22 \%, 15 \%$, and $14 \%$, respectively) were the main contributors of the total Ecological Footprint of the NPEMT. The area of the NPEMT is able to meet the needs of its population provided that the consumption patterns will be stable. The results encourage the expansion of tourism development, as the tourism activity within the NPEMT is limited compared to other adjacent domestic destinations.
\end{abstract}

Keywords: carrying capacity; regional sustainability assessment; ecological footprint; national park 


\section{Introduction}

Sustainable development requires human systems to function within specific "green" limits to ensure the sufficient supply of goods and services both to current and future generations [1]. The achievement of sustainability in an area depends on whether the impact of anthropogenic activities are within the "green" range, including those activities that take place outside the examined area but whose impacts affect its environmental status [2]. For this reason, the planning and natural resources management in all spatial scales is essential to aim toward sustainability [3].

Focusing on protected areas, the integration of anthropogenic activities within the boundaries of protected areas has led to increasing concerns regarding the appropriate use levels of parks, forests, lakes, and other environmentally sensitive areas [4]. Alongside the significant ecological habitats within protected areas, extensive human activities are developed such as households, tourism, agriculture, light industry, and transportation. The harmonious coexistence of those diverse activities is a basic concern of the management bodies responsible for protected areas [5]. More and more relevant authorities need to quantify and assess the maximum level of human activities that can be developed to satisfy current and future needs, while in parallel sustaining the environmental and ecological health.

The sustainability of protected areas is associated directly with Carrying Capacity for two reasons: (a) the idea of sustainability reflects a limit, similarly with the concept of Carrying Capacity, and (b) both concepts share the same challenges in formulating the objectives, practices, and actions of improvement [6]. From the early 1960s, due to the fact that public visits were the major threat for protected areas [7-10], research on outdoor recreation has utilized the concept of Carrying Capacity to address the resource and social impacts of visitors [7,11,12]. A number of frameworks [5,13-16] have been developed in order to provide management bodies with a basis for decision-making about the Carrying Capacity of national parks and protected areas, defining it as "the maximum number of visitors an area can sustain without unacceptable deterioration of the physical environment and without considerably diminishing user satisfaction" $[9,15,17]$. Therefore, in the current article, the concepts of Environmental Sustainability and Carrying Capacity are identical.

In Greece, there are twenty (20) protected areas [18] known for their great ecological and educational value, when at the same time, apart from tourism, several other human activities are traditionally and/or legally established within their boundaries. Thus, the assessment of the Carrying Capacity becomes more complex, since activities such as agriculture, livestock, aquaculture, households, light industry, and transportation have to be taken into account. Therefore, the Carrying Capacity assessment of an area must take into account the impact of all the activities that take place within its boundaries.

Serving this challenge, the aim of the specific study was to provide an applicable framework that is able to improve the evaluation and monitoring of the environmental sustainability of protected areas. The proposed framework takes advantages from the results of an extensive literature review we have conducted in a previous work [19]. In this work, 13 methods selected from a pool of 61 methods from a literature review were analyzed, categorized, and were finally evaluated based on specific criteria $[19,20]$. This analysis pointed out key conclusions related to the efficiency and the applicability of environmental sustainability assessment methods of protected areas. More specifically, the "Resource Availability Assessment" category of methods and especially the "Ecological Footprint" method have been indicated as the most appropriate method for the evaluation of environmental sustainability of protected areas. Moreover, the need for the improvement of the ability of methods to incorporate new activities within the environmental boundaries of the protected area, together with the necessity of the methods to provide environmental sustainability thresholds, in order to evaluate quantitatively whether the performance is sustainable, was also pointed out. An effective environmental sustainability assessment method should take into account the spatial characteristics of the examined area and ensure an adequate balance between the level of complexity and the coverage of key sustainability issues $[19,20]$.

This paper consolidates key findings from our previous work on the evaluation of existing environmental sustainability assessment methods [19] and progresses a step forward by integrating all 
the information into an applicable framework that focuses on protected areas, taking into consideration all anthropogenic activities within its boundaries. The proposed framework is expected to provide a more holistic approach for the assessment of the environmental status and for the development of a sustainable strategy for a protected area.

\section{Method Description}

In this specific section, the theoretical background and the steps that compose the proposed methodological framework are briefly presented.

\subsection{Theoretical Background}

The concept of Carrying Capacity in general expresses an upper limit of the ability to sustain a living system, whereas beyond that limit, instability, degradation, or irreversible damage will subsequently occur [21]. Therefore, Carrying Capacity can be utilized as a supportive tool of policy and decision-making, in order to resolve the aforementioned challenges.

The assessment of the Carrying Capacity of an area is a case-specific procedure and depends on the nature of the problem to be solved and the objectives set by the researcher. As a result, various Carrying Capacity definitions are available in literature. A widely known definition was introduced by Rees [22], according to which the Carrying Capacity of an ecosystem is "the maximum population of certain species that can be accommodated in an environment without permanent damage to the productivity of the environment".

All human populations need natural resources. The use of resources leads to physical outputs that affect global and local areas and has environmental impacts, such as waste generation and impact on climate change. The availability of natural resources and the environmental impacts from their utilization are the two restrictive parameters regulating the size of the population that can be sustained in a given area [23].

Thus, the majority of existing Carrying Capacity methodologies focus on the environmental constraints of resource consumption to determine population limits [24]. The resource-consumptionfocused methodologies $[25,26]$ are universally applicable, reasonably comprehensive, and their data and methodology have been made publicly available [27]. The most common current existing examples of environmental modeling [24,28,29] are based on the Ecological Footprint, "the amount of land and/or water that is necessary to a population or activity, in order to produce, in a sustainable way, all the natural resources it consumes and assimilate the waste it produces, using the available technology" [30].

Therefore, both Ecological Footprint and Carrying Capacity are based on similar procedures such as defining an area, selecting resources, and defining relevant indicators for qualification [28]. In order to assess the Carrying Capacity of an entity, its Ecological Footprint per person is compared with its Biocapacity, a term that represents the available biologically productive land that absorbs the impact of consumption along with subsequent waste [25]. The Ecological Footprint calculations refer to the estimation of annual consumption needs of anthropogenic activities that take place on the study area and their conversion to biologically productive land. According to Wackernagel et al. [31], the aforementioned consumption needs are classified into six (6) Ecological Footprint land use types, namely, agricultural products, livestock products, fishery and aquaculture, timber products, $\mathrm{CO}_{2}$ emissions, and built-up surfaces. The Ecological Footprint of consumption for each product $(\mathrm{EFc})$ is calculated as:

$$
\mathrm{EF}_{\mathrm{C}}=\mathrm{EF}_{\mathrm{P}}+\mathrm{EF}_{\mathrm{im}}-\mathrm{EF}_{\mathrm{ex}}
$$

where $\mathrm{EF}_{\mathrm{P}}$ is the Ecological Footprint of production, and $\mathrm{EF}_{\mathrm{im}}$ and $\mathrm{EF}_{\mathrm{ex}}$ are the Ecological Footprints embodied in imported and exported commodity flows, respectively.

In order to ensure that all the production procedures as well as the necessary materials both for product production or energy generation will be taken into account in the estimation of the Ecological Footprint, the Life Cycle Analysis (LCA) approach was innovatively applied, leading to a more thorough assessment of human activities and ensuring that all required processes and materials were 
taken into account in the calculations [32]. The Life Cycle Analysis is conventionally characterized as a "cradle-to-grave" or "closed-loop" approach, as it examines the overall environmental impact of a product, process, or system, taking into account every step of its life-from receipt of raw materials to its construction, its sale, usage, and final disposal into the environment [33].

The Biocapacity calculations refer to the estimation of the existing available biologically productive land. The available land is divided into five land uses, namely, cropland area, grazing land area, marine/inland water area, forest area, and infrastructure area [31].

The calculation of Biocapacity is implemented based on the accounting framework proposed by Wackernagel et al. [31]. The available productive areas were firstly converted into land in terms of world average productivity by multiplying the available hectares of each land use with the corresponding "yield factors" [34]. "The Yield Factors (YFs) account for countries' differing levels of productivity for particular land uses are country-specific and vary by land use type and year. They may reflect natural factors such as differences in precipitation or soil quality, as well as anthropogenic differences such as management practices" [34]. Subsequently, the abovementioned lands were converted to Biocapacity by multiplying the world hectares of each land use with the corresponding "equivalence factor" [34]. "The Equivalence Factors (EQFs) convert the areas of different land uses, at their respective world average productivities, into their equivalent areas at global average bioproductivity across all land use and they vary by land use as well as by year. The rationale behind the Equivalent Factor calculation is to weight different land areas in terms of their inherent capacity to produce human useful biological resources. The weighting criterion is not the actual quantity of biomass produced, but what each hectare would be able to inherently deliver" [34]. The values of the mentioned parameters of yield factor and equivalence factor are retrieved by available references and databases [35,36]. Finally, the Biocapacities of land uses are summed to the total Biocapacity.

The proposed framework is based on the "Ecological Footprint" calculation framework described above, but goes a big step further by simplifying the Ecological Footprint calculations and introducing a new unit, namely, "equivalent person," in order to enable the evaluation of more than one activity.

\subsection{Methodological Framework Description}

The methodological framework has been developed for estimating the Carrying Capacity of an anthropogenic spatial entity, which refers to the spatial scale below a nation and usually includes a province or a municipality or parts of them that are administrated under a specific management scheme or other specific authority (e.g., National Park) and it is summarized in Figure 1.

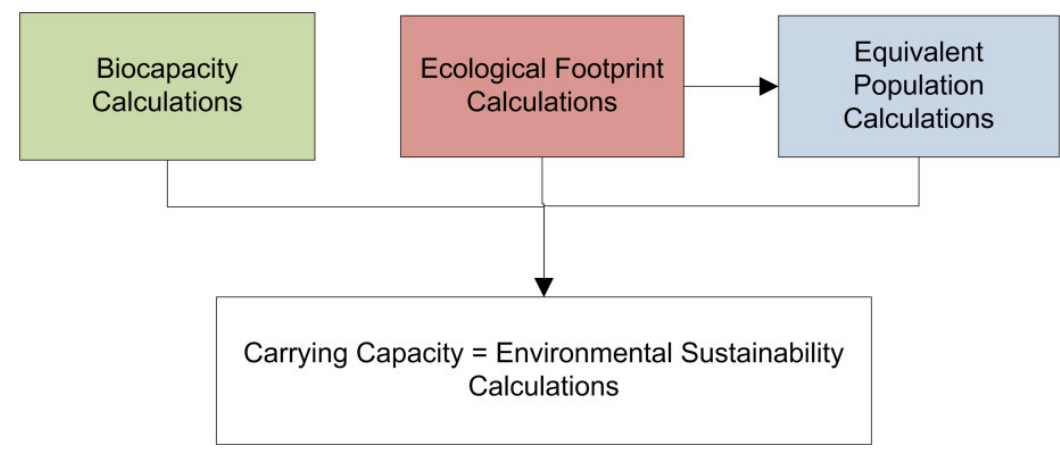

Figure 1. The proposed framework.

Based on the above, a comprehensive quantitative definition of Carrying Capacity is given by the authors with the following formula:

$$
\text { Carrying Capacity (max.equivalent population) }=\frac{\text { Biocapacity (available land) }}{\frac{\text { Ecological Footprint (required land) }}{P(\text { existing equivalent population })}}
$$


where $P$ is the existing equivalent population of the inhabitants of the spatial entity under study. The unit of "equivalent population" is introduced, since the proposed methodological framework besides the consumption needs of the real human population of the study area estimates the consumption needs of anthropogenic activities, which are not directly dependent on the size of the real population. For example, the annual energy consumption of buildings depends on their size and their use and not on the population size of the study area.

At first, the spatial and time parameters of the framework, namely the geographical boundaries of the study area and the reference year essential for the procedure of data acquiring, are clarified. Following, the calculations are separated in three sectors: (a) Biocapacity calculations, (b) Ecological Footprint calculations, and (c) Calculations of existing Equivalent population.

\subsubsection{Biocapacity's Accounts}

In order to calculate Biocapacity, specific indicators per land use of the CORINE (Coordination of Information on the Environment) land cover methodology [37] were used. These indicators are presented in Figure 2. The available productive land was estimated with the application of a GIS (Geographic Information System) software compatible with the European databases for land uses. Then the available productive lands were converted to Biocapacity per land use by multiplying the available hectares per land use firstly with the yield factors and then with the corresponding equivalent factors, both known from the literature. The total Biocapacity is the sum of all Biocapacities per land use.

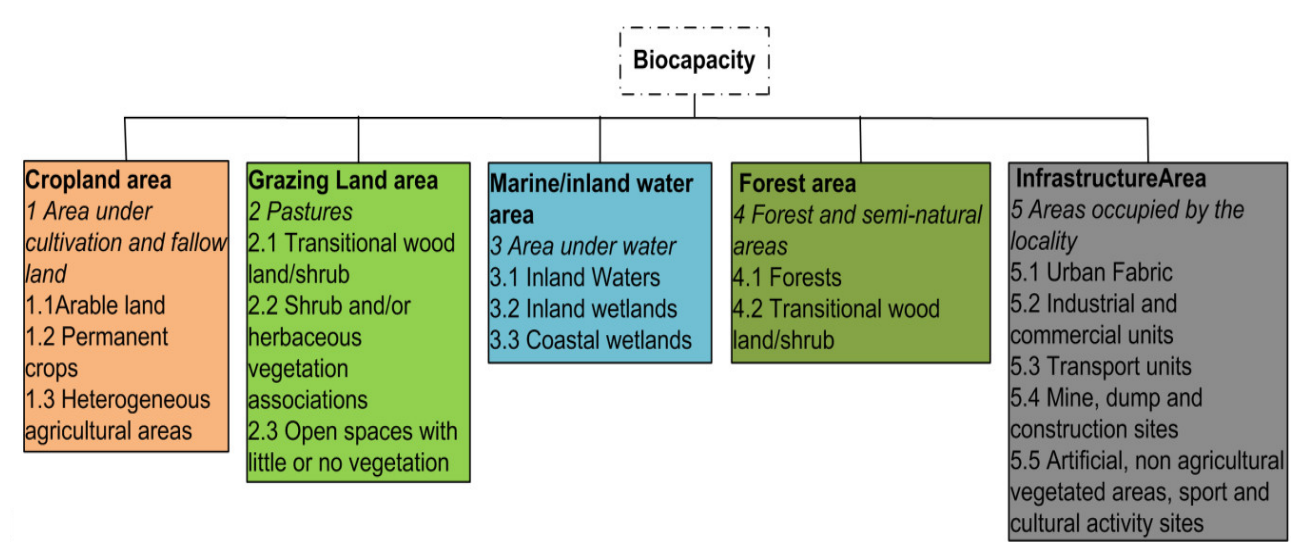

Figure 2. The indicators of Biocapacity per land use.

\subsubsection{Ecological Footprint's Accounts}

"The Ecological Footprint theoretically includes all human demands, but in practice, the relevant datasets are not available" [34]. Thus, taking into consideration the availability of datasets from similar studies $[35,38]$ and trying to simplifying the Ecological Footprint calculations framework, the selection of the relevant parameters for energy and product consumption was implemented. The energy and product consumption were related to the needs of households, tertiary sector, municipal buildings, public lighting, public and private transportation, and tourism activities. The selected indicators for the Ecological Footprint assessment are presented in Figure 3, and an indicative sample of them is described in detail in Appendix A.

For the estimation of individual annual consumption, an inventory including indicative quantitative data is implemented. Depending on the availability of data, certain assumptions may be necessary. In order to improve the functionality of the framework, an algorithm that calculates the values of the individual indicators was developed providing that several inputs are known. The algorithm accepts numerous inputs, such as number of residents and tourists, number of buildings per use, area of dwellings, installed power, length of road and railway networks, numbers of vehicles per mean of transportation (cars, motorbikes, etc.), number of passengers and loads for commercial 
and passenger ships and airplanes, etc. (see Appendix A). The calculations were implemented taking into account assumptions, such as average weight of residents and tourists, average consumption of products per $\mathrm{kg}$ of human mass per day, average electrical and thermal energy per $\mathrm{m}^{2}$ per use of building, average surface of buildings per use, average time of public lighting's operation per year, average distance travelled by vehicles on local roads per year, average weight of loads for commercial and passenger ships, etc. (see Appendix A).

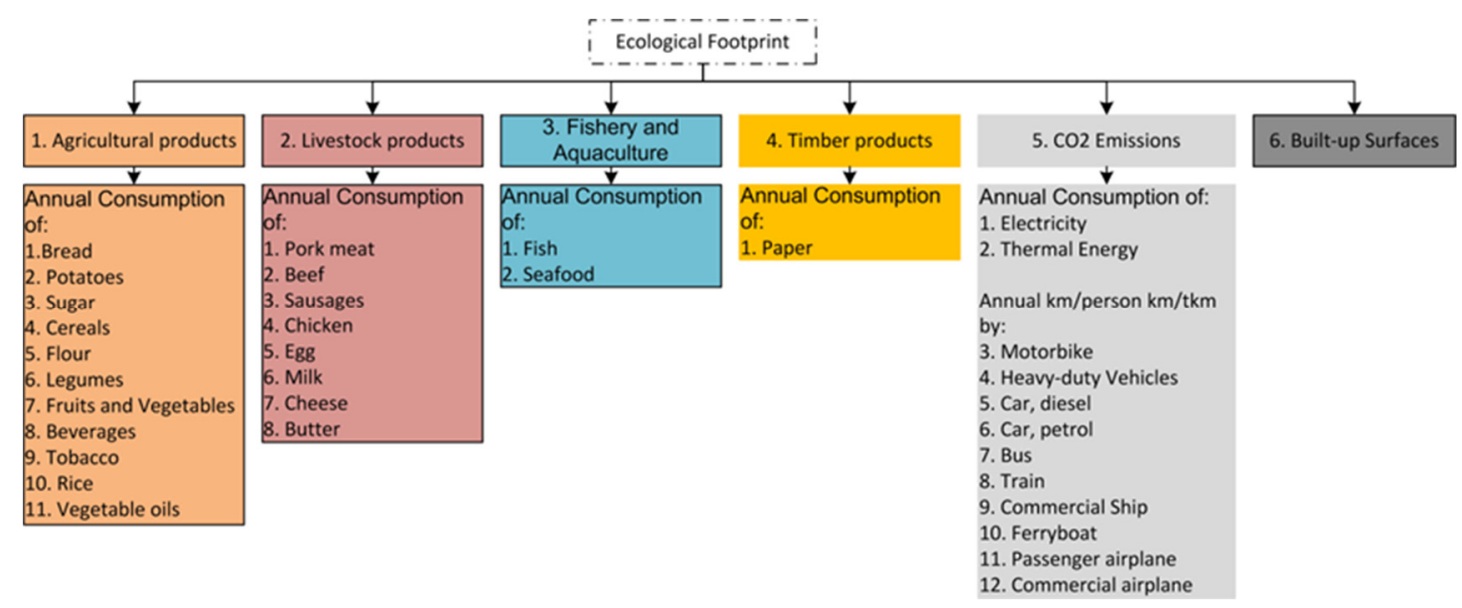

Figure 3. The Ecological Footprint's indicators per land use.

For the conversion of the aforementioned annual consumption in required biologically productive land, proper factors were developed with the application of LCA software (SimaPro 7.2) and the methodology Ecological Footprint V 1.02, and were used.

\subsubsection{Equivalent Population's Accounts}

An innovative part of the proposed framework is the calculation of the existing equivalent population that refers to the estimation of resident population (real and equivalent) of the study area, which contributes to the total annual consumption of resources and energy. The proposed methodological framework for the estimation of the total Ecological Footprint, besides the consumption needs of real residents of the study area, also takes into account the annual consumption of activities that do not depend directly on the resident population, such as the annual fuels consumption for personal transportation, which depends on the annual travelled $\mathrm{km}$ by all types of vehicles (cars, motorbikes, trucks, etc.), the annual energy consumption of tertiary sector buildings (hospitals, shops, offices, etc.) that depends on the surface area, etc. Consequently, an equivalence between the consumption needs and the equivalent resident was created, according to the Ecological Footprint that these needs require. By setting the real residents' population of the study area and their needs as a basis, the consumption needs of the remaining anthropogenic activities are matched to equivalent residents. Using this method, every real resident is matched to one equivalent resident, while all the other activities "produce" a corresponding number of equivalent residents. For example, a population of $\mathrm{X}$ equivalent residents can be sustained with the Ecological Footprint corresponding to the annual power consumption of tertiary sector buildings, or moreover, a population of $Y$ equivalent residents can be sustained with the Ecological Footprint corresponding to the annual fuel consumption for personal transportation, etc.

The calculation of the existing equivalent residents which contributes to the total Ecological Footprint is implemented by considering the following hypothesis: if $\mathrm{P}^{*}$ real residents need $\mathrm{EF}^{*}$ (area in Gha) to be sustained, then what is the number of residents $\left(\mathrm{P}_{\text {eq }}\right)$ able to be sustained in EF (area in Gha)? The existing equivalent resident population is therefore calculated using Equation (3):

$$
\text { Peq }=\frac{\mathrm{P}^{*}}{\mathrm{EF}^{*}} E F
$$


where $\mathrm{P}^{*}$ and $\mathrm{EF}^{*}$ represent the population and the Ecological Footprint of the real residents, and $\mathrm{EF}$ represents the total Ecological Footprint of the spatial entity under study.

\section{Case Study: National Park of Eastern Macedonia and Thrace, Greece}

The proposed framework was applied to the National Park of Eastern Macedonia and Thrace (NPEMT), in Greece, in order to verify and improve its applicability.

\subsection{Description of the Study Area}

The National Park of Eastern Macedonia and Thrace (NPEMT) covers approximately 73,000 ha and includes the wetlands of Delta Nestos and Lakes Vistonida and Ismarida (Figure 4). Within the NPEMT, habitats of significant biodiversity and ecological value are in coexistence with extensive human activities (urban, rural, tourist, industrial). The NPEMT extends to the administrative boundaries of six (6) municipalities, has 43 villages, 10,500 households, and an approximate population of 29,000 people.

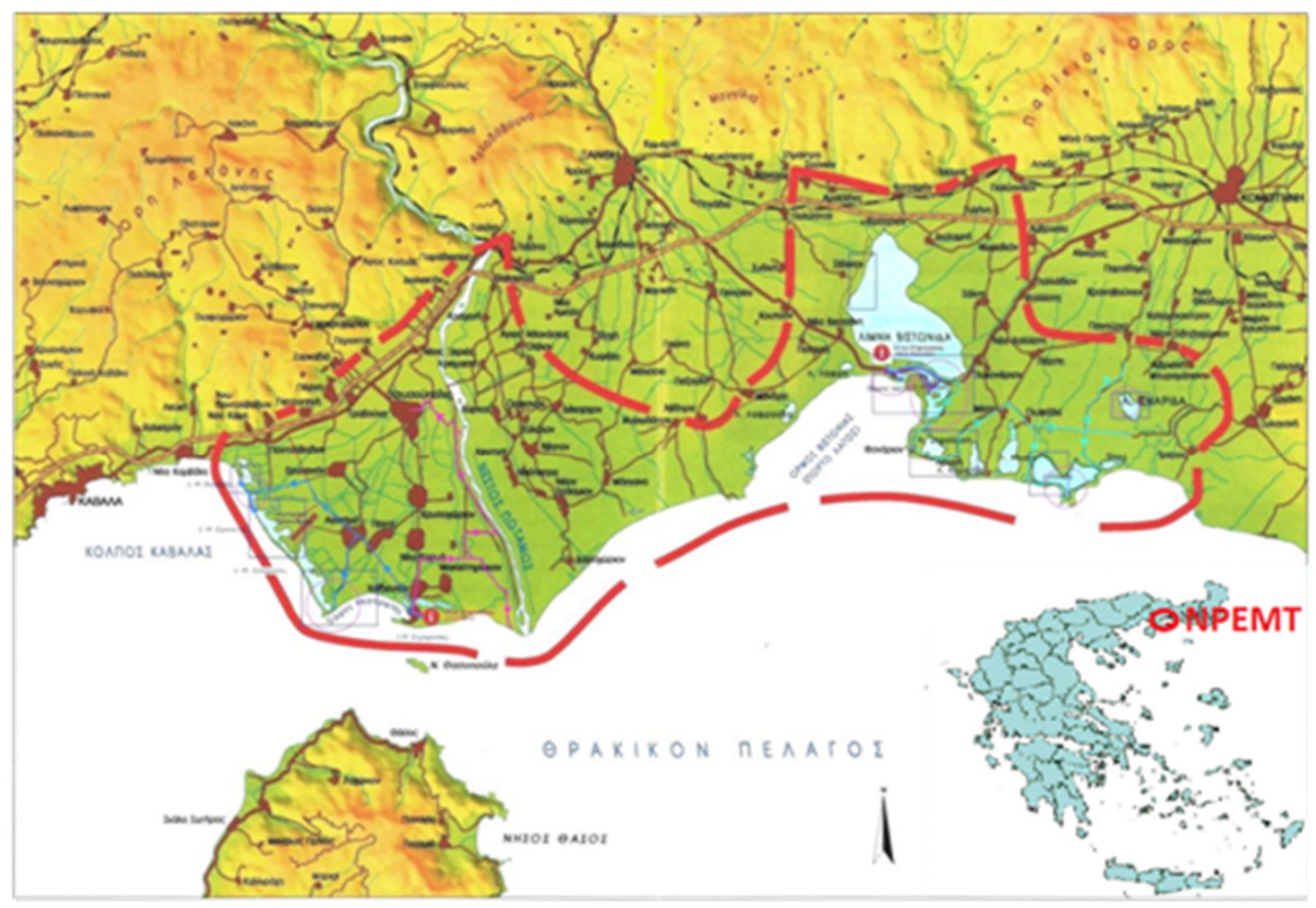

Figure 4. The geographical boundaries of the National Park of Eastern Macedonia and Thrace (NPEMT).

The main characteristics of the NPEMT area are summarized below:

- The building stock of the NPEMT is constituted by 15,400 dwellings, 820 offices and commercial buildings, 8 healthcare buildings, 100 schools, and 30 hotels.

- The total installed power for public lighting is $700 \mathrm{~kW}$.

- Approximately 3.5 million cars, 4000 motorbikes, and 670,000 heavy-duty vehicles use the national, provincial, and local road networks set within the boundaries of the NPEMT on an annual basis.

- The railway within the boundaries of the NPEMT has a length of $10.5 \mathrm{~km}$ and serves 146,000 people annually.

- At the two ports of the area, 9160 arrivals and departures are performed, transferring 140,000 people, 463,000 vehicles, and 194,000 tons of commodities on an annual basis.

- The local airport serves approximately 210,000 people (native and tourists) and 300 tons of commodities annually. 
- The total number of visitors that stay at least one night within the NPEMT area is estimated at approximately 25,000 .

\subsection{Implementation of the Methodological Framework}

The available land uses and subareas of the NPEMT were measured using the software Mapinfo Professional 12.0 and data from the European program for land cover CORINE (Coordination of Information on the Environment) 2000 [39] (see Table 1). The Biocapacity of the NPEMT was therefore estimated at 192,283 hectares of biologically productive land (area in Gha).

Table 1. The calculations of the Biocapacity of the NPEMT.

\begin{tabular}{ccccc}
\hline Land Uses & Area in ha & Yield Factor * $^{*}$ & Equivalent Factor * $^{\text {B }}$ & Biocapacity (Gha) \\
\hline Cropland Area & 52,011 & 1.5 & 2.2 & 171,472 \\
Grazing Land Area & 4528 & 4.1 & 0.5 & 9283 \\
Marine/ Inland & 12,284 & 0.8 & 0.4 & 3931 \\
Water Area & 910 & 1.3 & 1.4 & 1657 \\
Forest Area & 1800 & 1.5 & 2.2 & 5940 \\
Infrastructure Area & Total Biocapacity of the NPEMT & & 192,283 \\
\hline
\end{tabular}

* Source: [35].

The results from the estimation of Ecological Footprint for the reference year (2013) are presented in Table 2. Relative estimations took place for the Ecological Footprint calculation, deriving by the real resident population of the NPEMT, which was estimated at 143,628 Gha.

The existing equivalent resident population of the NPEMT was calculated using Equation (3) to 36,960 equivalent residents.

$$
\mathrm{P}_{\text {eq }}=\frac{P_{1}}{E F_{1}} E F=\frac{29,276}{143,628} 181,324=36,960 \text { equivalent residents }
$$

Table 2. The calculation of the Ecological Footprint in the totality of the NPEMT.

\begin{tabular}{|c|c|c|c|c|}
\hline $\begin{array}{l}\text { Ecological Footprint } \\
\text { Subcategory }\end{array}$ & Ind. Code & Annual Consumptions/Activities & $\begin{array}{l}\text { Residents' Ecological } \\
\text { Footprint in Gha }\end{array}$ & $\begin{array}{l}\text { Total Ecological } \\
\text { Footprint in Gha }\end{array}$ \\
\hline \multirow{11}{*}{ 1. Agricultural Products } & Ind. EF 1.1 & Bread & 671 & 676 \\
\hline & Ind. EF 1.2 & Potatoes & 399 & 402 \\
\hline & Ind. EF 1.3 & Sugar & 92 & 92 \\
\hline & Ind. EF 1.4 & Cereals & 728 & 733 \\
\hline & Ind. EF 1.5 & Flour & 260 & 261 \\
\hline & Ind. EF 1.6 & Legumes & 2509 & 2527 \\
\hline & Ind. EF 1.7 & Fruits and Vegetables & 27,313 & 27,502 \\
\hline & Ind. EF 1.8 & Beverages & 25,759 & 25,938 \\
\hline & Ind. EF 1.9 & Tobacco & 77 & 78 \\
\hline & Ind. EF 1.10 & Rice & 3912 & 3939 \\
\hline & Ind. EF 1.11 & Vegetable oils & 2298 & 2314 \\
\hline \multirow{8}{*}{ 2. Livestock Products } & Ind. EF 2.1 & Pork meat & 4141 & 4170 \\
\hline & Ind. EF 2.2 & Beef & 40,965 & 41,249 \\
\hline & Ind. EF 2.3 & Sausages & 1882 & 1895 \\
\hline & Ind. EF 2.4 & Chicken & 1506 & 1516 \\
\hline & Ind. EF 2.5 & Egg & 909 & 916 \\
\hline & Ind. EF 2.6 & Milk & 4111 & 4140 \\
\hline & Ind. EF 2.7 & Cheese & 206 & 207 \\
\hline & Ind. EF 2.8 & Butter & 6 & 6 \\
\hline \multirow{2}{*}{$\begin{array}{l}\text { 3. Fishery/Aquaculture } \\
\text { products }\end{array}$} & Ind. EF 3.1 & Fish & 3928 & 3956 \\
\hline & Ind. EF 3.2 & Seafood & 107 & 107 \\
\hline
\end{tabular}


Table 2. Cont.

\begin{tabular}{|c|c|c|c|c|}
\hline $\begin{array}{l}\text { Ecological Footprint } \\
\text { Subcategory }\end{array}$ & Ind. Code & Annual Consumptions/Activities & $\begin{array}{l}\text { Residents' Ecological } \\
\text { Footprint in Gha }\end{array}$ & $\begin{array}{l}\text { Total Ecological } \\
\text { Footprint in Gha }\end{array}$ \\
\hline 4.Timber products & Ind. EF 4.1 & Paper & 951 & 951 \\
\hline \multirow{6}{*}{ 5. $\mathrm{CO}_{2}$ emissions } & Ind. EF 5.1 & Electricity & 11,159 & 21,898 \\
\hline & Ind. EF 5.2 & Thermal Energy & 9739 & 13,717 \\
\hline & Ind. EF 5.3 & Transportation by motorbike & 0 & 830 \\
\hline & Ind. EF 5.4 & $\begin{array}{l}\text { Transportation by } \\
\text { heavy-duty vehicle }\end{array}$ & 0 & 9784 \\
\hline & Ind. EF 5.5 & Transportation by car (diesel) & 0 & 1093 \\
\hline & Ind. EF 5.6 & Transportation by car (petrol) & 0 & 5883 \\
\hline & Ind. EF 5.7 & Transportation by bus & 0 & 322 \\
\hline & Ind. EF 5.8 & Transportation by train & 0 & 20 \\
\hline & Ind. EF 5.9 & Transportation by commercial ship & 0 & 3 \\
\hline & Ind. EF 5.10 & Transportation by ferryboat & 0 & 20 \\
\hline & Ind. EF 5.11 & Transportation by passenger aircraft & 0 & 215 \\
\hline & Ind. EF 5.12 & $\begin{array}{l}\text { Transportation by } \\
\text { commercial aircraft }\end{array}$ & 0 & 3 \\
\hline 6. Built-up surfaces & Ind. EF 6.1 & Built-up areas * & 0 & 3960 \\
\hline \multicolumn{3}{|c|}{ Total EF of the NPEMT } & 143,628 & 181,324 \\
\hline
\end{tabular}

${ }^{*}$ Built-up areas were estimated for the totality of the NPEMT and not separately for every activity due to lack of available data.

The Carrying Capacity of the NPEMT was calculated using Equation (2) to 39,193 equivalent residents.

$$
C C=\frac{B c}{\frac{E F}{P e q}}=\frac{192,283}{\frac{181,324}{36,960}}=39,193 \text { equivalent residents }
$$

\subsection{Results and Discussion}

The Ecological Footprint of the NPEMT was estimated at 181,324 Gha or $4.9 \mathrm{Gha} /$ pers eq, slightly higher than the European mean (4.69 Gha/pers eq) [36], whereas the Biocapacity of the NPEMT was estimated at 192,283 Gha. The Carrying Capacity of the NPEMT was estimated at 39,193 equivalent residents; a number higher than the existing equivalent residents (36,960 equivalent residents). Therefore, the area is able to meet the needs of its population provided that the consumption patterns will be stable or more efficient. Also, there is a considerable margin for the development of new activities within the NPEMT boundaries. More specifically, regarding the tourism activity, although it is a common problem in protected areas worldwide, the NPEMT has a Carrying Capacity surplus of approximately 2000 equivalent residents, indicating that it can support a certain number of extra tourists annually.

The major contributors on the total Ecological Footprint of the NPEMT were the annual consumptions of products and energy related with households $(79 \%)$ and the annual consumption of energy related with private transportation $(10 \%)$, as shown in Table 3.

Analyzing the Ecological Footprint of the NPEMT into its land uses as it is presented in Figure 5, it can be observed that the main contributors are "1. Agricultural products" (36\%), "2. Livestock products" (30\%), and "5. $\mathrm{CO}_{2}$ Emissions" (30\%). It is remarkable that the consumption needs of products and energy correspond to approximately $68 \%$ and $30 \%$, respectively, of total Ecological Footprint. Among the products, beef annual consumption (22.8\%) was identified as the key factor contributing to the Ecological Footprint of the spatial entity under study, while fruits and vegetables $(15.2 \%)$ and beverages (14.3\%) followed. The above results are in agreement with the literature [40], which indicates food consumption as a key contributor to the Ecological Footprint in areas where human activities exist. Potential changes in the nutritional habits of residents and tourists, such as partial replacing of beef, could significantly reduce the total Ecological Footprint. 
Table 3. The contribution of several human activities on the total Ecological Footprint of the NPEMT.

\begin{tabular}{ccc}
\hline Description of Human Activities & Ecological Footprint & $\begin{array}{c}\text { \% of the Total Ecological } \\
\text { Footprint of the NPEMT }\end{array}$ \\
\hline Products and energy consumption for households & $143,628.3$ & $79 \%$ \\
Energy consumption for buildings of tertiary sector & $10,285.8$ & $6 \%$ \\
Energy consumption for municipal buildings & 1327.5 & $1 \%$ \\
Energy consumption for public lighting & 776.7 & $0 \%$ \\
Distance travelled by means of private transportation & $17,304.6$ & $10 \%$ \\
Distance travelled by means of public transportation & 868.2 & $0 \%$ \\
Products and energy consumption for tourism & 3172.7 & $2 \%$ \\
Built-up areas & 3960.0 & $2 \%$ \\
\hline Total & $181,324.0$ & 100 \\
\hline
\end{tabular}

The fact that the proposed framework has been applied effectively to the NPEMT is encouraging in relation to its applicability. Also, the development of the algorithm that calculates the Ecological Footprint, the Biocapacity, and the Carrying Capacity of the protected area under study by introducing 48 inputs has reduced the complexity and the expertise needed for the implementation of the proposed framework. The evaluation of the environmental sustainability of the protected area under study has been elaborated in a holistic approach taking into account anthropogenic activities. Moreover, the results of the framework can provide clear information about the progress towards sustainability and the ability to incorporate new activities within the environmental boundaries of the protected area under study.

On the other hand, the authors recognize a certain degree of subjectivity in the evaluation process which is related to the application of certain assumptions required due to the lack of data. All assumptions are supported by statistical data, surveys, literature references [41,42], etc. Moreover, there was no provision for the implementation of an uncertainty and sensitivity analysis method in order to identify and cope with the uncertainties raised by the integration of the LCA method in the proposed framework.

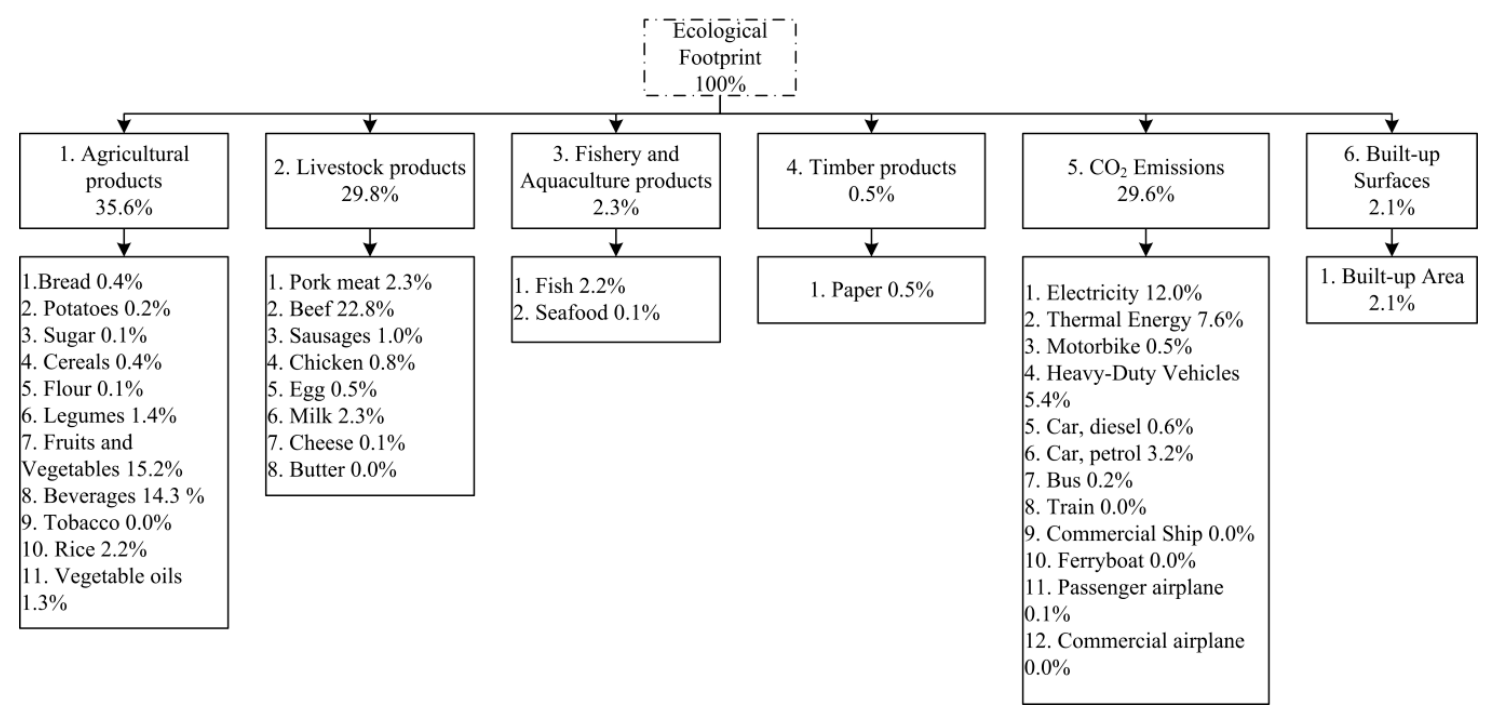

Figure 5. The Ecological Footprint results of the NPEMT.

\section{Conclusions}

The current work introduced a methodological framework that is able to evaluate the Environmental Sustainability of a spatial entity with anthropogenic activities and applied it to the National Park of Eastern Macedonia and Thrace. The key advantage of the proposed framework is that it can assess entities that present various human activities, such as households, tertiary sector, 
tourism, and transportation. In order to achieve this, the proposed methodological framework equates the meaning of Environmental Sustainability to Carrying Capacity, estimating the maximum equivalent population of residents which can live sustainably within a spatial entity. For this estimation, the following are considered: (a) the available biologically productive land (Biocapacity) of the spatial entity, (b) the land needed to satisfy the consumption needs of the anthropogenic activities in products and energy (Ecological Footprint) within the spatial entity, and (c) the real value of the equivalent residents, since all the consumption needs of the anthropogenic activities are not directly connected to the population size. For example, the energy consumption of buildings depends on their surface and use and not on the number of residents. The value of Carrying Capacity comes from the division of Biocapacity to Ecological Footprint per equivalent capita (EF/Peq).

The implementation of the proposed framework contributes to the improvement of the functionality and applicability of the existing methods for evaluating the environmental sustainability of protected areas, while providing clear information about the progress toward sustainability and the ability to incorporate a new activity within the boundaries of the protected area under study. However, particular points, related to the assumptions and the uncertainties, have been identified that need to be improved in order to strengthen the objectivity of the evaluation process and to treat the uncertainties due to the integration of the LCA approach.

Especially, the results from the application of the proposed framework in the NPEMT indicated a positive environmental performance of the region, since the Carrying Capacity is calculated at 39,193 equivalent residents, when the existing equivalent population was estimated at 36,960 equivalent residents. Therefore, the area is able to meet the needs of its equivalent population provided that the consumption patterns will be stable or improved. The results encourage a sensible expansion of touristic activities. Household activities are the main contributor (79\%) to the total Ecological Footprint, whereas product consumption is responsible for $68 \%$ of the total Ecological Footprint, which is in agreement with other studies.

The authors are planning to continuously improve the effectiveness of the proposed framework by developing supporting software that will enable its fast and reliable implementation and by applying an uncertainty analysis for different scenarios in order to strengthen the reliability and credibility of the integration of the LCA approach in the proposed framework. Another key issue that needs to be examined in the future is the potential assistance of an experts group in order to determine the values of the assumptions needed in a more objective process.

The management bodies of protected areas have to advise the Public Administration on the sustainability of new projects to be carried out within their boundaries and to develop sustainable strategies ensuring the harmonious coexistence of natural capital with proposed anthropogenic activities. Therefore, both the management bodies of the protected areas and the accountable administrative authorities need to assess and quantify the impact of existing and future human activities that can be developed to satisfy current and future needs, while in parallel sustaining the environmental and ecological health. The proposed Environmental Sustainability Assessment framework can serve as a tool to support decision-making through Carrying Capacity estimation and monitoring.

Author Contributions: All authors contributed equally to the text. All authors have read and agreed to the published version of the manuscript.

Funding: This research received no external funding.

Acknowledgments: The authors would like to thank the NPEMT Management Body for supporting the case study implementation.

Conflicts of Interest: The authors declare no conflict of interest. 


\section{Appendix A}

Table A1. The Ecological Footprint indicators.

\begin{tabular}{|c|c|c|c|c|}
\hline Indicator & Calculation & Available Assumptions & Available Inputs & Activities to Apply \\
\hline $\begin{array}{c}{ }^{1} \text { Bread: } \\
\text { Annual bread consumption }\end{array}$ & $\begin{array}{l}\text { Average consumption of bread in } \mathrm{g} \text { per } \mathrm{kg} \text { of } \\
\text { human mass per dayX days of consumption } \\
\mathrm{X} \text { average weight } \mathrm{X} \text { number of persons }\end{array}$ & $\begin{array}{c}\text { Average weight in } \mathrm{kg} \text { of adult residents } \\
\text { Average weight in kg of adult tourists } \\
\text { Average weight in kg of minor residents } \\
\text { Average weight in kg of minor tourists } \\
\text { (3) Days per year of consumption for residents } \\
\text { (4) Days per year of consumption for residents } \\
\text { (5) Average consumption of bread in g per kg of human mass } \\
\text { per day }\end{array}$ & $\begin{array}{l}\text { (1) Number of adult residents } \\
\text { (2) Number of minor residents } \\
\text { (3) Number of adult tourists } \\
\text { (4) Number of minor tourists }\end{array}$ & $\begin{array}{c}\text { Households } \\
\text { Tourism }\end{array}$ \\
\hline $\begin{array}{c}\text { Paper: } \\
\text { Annual paper consumption }\end{array}$ & $\begin{array}{l}\text { Average consumption of paper per capita per } \\
\text { year } X \text { number of residents }\end{array}$ & Average consumption in $t$ of paper per capita per year in Greece & $\begin{array}{l}\text { (1) Number of adult residents } \\
\text { (2) Number of minor residents }\end{array}$ & Households \\
\hline
\end{tabular}


Table A1. Cont.

\begin{tabular}{|c|c|c|c|c|}
\hline Indicator & Calculation & Available Assumptions & Available Inputs & Activities to Apply \\
\hline & & $\begin{array}{c}\text { (10) Average surface }\left(\mathrm{m}^{2}\right) \text { of healthcare buildings built } \\
\text { before } 1980 \\
\text { (11) Average surface }\left(\mathrm{m}^{2}\right) \text { of healthcare buildings built } \\
\text { between } 1981 \text { and } 2001 \\
2001 \\
\text { (12) Average surface }\left(\mathrm{m}^{2}\right) \text { of healthcare buildings built after } \\
\text { (13) Average electrical energy consumption per } \mathrm{m}^{2} \text { for } \\
\text { schools } 1980 \text { in } \mathrm{kWh} / \mathrm{m}^{2} \\
\text { (14) Average electrical energy consumption per } \mathrm{m}^{2} \text { for } \\
\text { schools } 2001 \text { in } \mathrm{kWh} / \mathrm{m}^{2}\end{array}$ & $\begin{array}{l}\text { (10) Number of hotels built before } 1980 \\
\text { (11) Number of hotels built between } 1981 \\
\text { and } 2001 \\
\text { (12) Number of hotels built after } 2002\end{array}$ & \\
\hline $\begin{array}{l}\text { Annual electricity consumption } \\
\text { in public lighting }\end{array}$ & $\begin{array}{l}\text { Average time of lighting operation } \mathrm{X} \\
\text { Installed power for public lighting }\end{array}$ & (1) Average time of lighting operation per year in hours & $\begin{array}{l}\text { (1) Installed power for public lighting in } \\
\mathrm{kW}\end{array}$ & Public Lighting \\
\hline
\end{tabular}


Table A1. Cont.

\begin{tabular}{|c|c|c|c|c|}
\hline Indicator & Calculation & Available Assumptions & Available Inputs & Activities to Apply \\
\hline $\begin{array}{l}\text { Distance travelled by means of } \\
\text { private and public } \\
\text { transportation (motorbikes, cars, } \\
\text { and heavy-duty vehicles) }\end{array}$ & $\begin{array}{l}\text { Average km passing by vehicle } X \\
\text { Number of private/public vehicles }\end{array}$ & $\begin{array}{l}\text { Average } \mathrm{km} \text { travelled by vehicles on local roads per year } \\
\text { The national percentage of cars fueled by diesel } \\
\text { The national percentage of cars fueled by petrol }\end{array}$ & $\begin{array}{c}\text { Number of private motorbikes moving } \\
\text { on local roads } \\
\text { Number of public motorbikes moving on } \\
\text { local roads } \\
\text { Number of private heavy-duty vehicles } \\
\text { moving on local roads } \\
\text { Number of private heavy-duty vehicles } \\
\text { moving on each part of the highway set } \\
\text { within the boundaries of the protected } \\
\text { area } \\
\text { km of each part of the highway set within } \\
\text { the boundaries of the protected area } \\
\text { Number of public heavy-duty vehicles } \\
\text { moving on local roads } \\
\text { Number of private cars moving on local } \\
\text { roads } \\
\text { Number of private cars moving on each } \\
\text { part of the highway set within the } \\
\text { boundaries of the protected area } \\
\text { Number of public car moving on local } \\
\text { roads. }\end{array}$ & $\begin{array}{l}\text { Public and Private } \\
\text { Transportation }\end{array}$ \\
\hline $\begin{array}{l}\text { Distance travelled by means of } \\
\text { public transportation (bus) }\end{array}$ & $\begin{array}{l}\text { km by bus within the boundaries of the } \\
\text { protected area }\end{array}$ & & $\begin{array}{l}\text { km by bus within the boundaries of the } \\
\text { protected area }\end{array}$ & $\begin{array}{c}\text { Public } \\
\text { Transportation }\end{array}$ \\
\hline $\begin{array}{l}\text { Distance travelled by means of } \\
\text { public transportation (train) }\end{array}$ & $\begin{array}{l}\text { Number of annual passenger } \mathrm{X} \mathrm{km} \text { of } \\
\text { local railway }\end{array}$ & & $\begin{array}{l}\text { (1) Number of annual passengers moving } \\
\text { by train on local railway } \\
\text { (2) km of local railway set within the } \\
\text { boundaries of the protected area }\end{array}$ & $\begin{array}{c}\text { Public } \\
\text { Transportation }\end{array}$ \\
\hline $\begin{array}{l}\text { Distance travelled by means of } \\
\text { public transportation } \\
\text { (commercial ship) }\end{array}$ & $\begin{array}{l}\mathrm{t} \text { loaded or/and unloaded from/to } \\
\text { commercial ship X km boarding port }\end{array}$ & & $\begin{array}{l}\text { t loaded or/and unloaded from/to } \\
\text { commercial ship in each port, } \\
\text { km boarding in each port }\end{array}$ & $\begin{array}{c}\text { Public } \\
\text { Transportation }\end{array}$ \\
\hline
\end{tabular}


Table A1. Cont.

\begin{tabular}{|c|c|c|c|c|}
\hline Indicator & Calculation & Available Assumptions & Available Inputs & Activities to Apply \\
\hline $\begin{array}{l}\text { Distance travelled by means of } \\
\text { public transportation (ferryboat) }\end{array}$ & $\begin{array}{l}\mathrm{t} \text { loaded or/and unloaded from/to } \\
\text { commercial ship } \mathrm{X} \mathrm{km} \text { boarding port }\end{array}$ & $\begin{array}{l}\text { (1) Average weight of a passenger in } t \\
\text { (2) Average weight of a heavy-duty vehicle in } t \\
\text { (3) Average weight of a bus in } t \\
\text { (4) Average weight of a car in } t \\
\text { (5) Average weight of a motorbike in } t\end{array}$ & $\begin{array}{c}\text { (1) km boarding at each port } \\
\text { (2) Number of passengers loaded to } \\
\text { ferryboat at each port } \\
\text { (3) Number of heavy-duty vehicles } \\
\text { loaded to ferryboat at each port } \\
\text { (4) Number of buses loaded to ferryboat } \\
\text { at each port } \\
\text { (5) Number of cars loaded to ferryboat at } \\
\text { each port } \\
\text { (6) Number of motorbikes loaded to } \\
\text { ferryboat at each port }\end{array}$ & $\begin{array}{c}\text { Public } \\
\text { Transportation }\end{array}$ \\
\hline $\begin{array}{l}\text { Distance travelled by means of } \\
\text { public transportation } \\
\text { (passenger aircraft) }\end{array}$ & $\begin{array}{c}\text { Number of passengers } X \mathrm{~km} \text { traveled } \\
\text { by airplane }\end{array}$ & & $\begin{array}{l}\text { (1) Number of passengers arrived by } \\
\text { airplane in each airport } \\
\text { (2) Number of passengers taking off by } \\
\text { airplane from each airport } \\
\text { (3) km travelled by airplane during } \\
\text { landing at each airport } \\
\text { (4) km travelled by airplane during } \\
\text { taking off at each airport }\end{array}$ & $\begin{array}{c}\text { Public } \\
\text { Transportation }\end{array}$ \\
\hline $\begin{array}{l}\text { Distance travelled by means of } \\
\text { public transportation } \\
\text { (commercial aircraft) }\end{array}$ & $\begin{array}{l}\text { t loaded/unloaded } X \mathrm{~km} \text { traveled by } \\
\text { airplane }\end{array}$ & & $\begin{array}{l}\text { (1) } t \text { loaded to airplane at each airport } \\
\text { (2) } t \text { unloaded from airplane at each } \\
\text { airport } \\
\text { (3) } \mathrm{km} \text { travelled by airplane during } \\
\text { landing at each airport } \\
\text { (4) } \mathrm{km} \text { travelled by airplane during } \\
\text { taking off at each airport }\end{array}$ & $\begin{array}{c}\text { Public } \\
\text { Transportation }\end{array}$ \\
\hline Built-up area & $\begin{array}{l}\text { Built-up Areas X Cropland Global } \\
\text { Equivalent Factor }\end{array}$ & & $\begin{array}{l}\text { Areas occupied by the locality (buildings, } \\
\text { roads, etc.) }\end{array}$ & \\
\hline
\end{tabular}

${ }^{1}$ All the product's consumptions (agricultural, livestock and fishery, and aquaculture products) were calculated similarly to the calculation of "bread consumption," replacing the average consumption of each product in $\mathrm{g}$ per $\mathrm{kg}$ of human mass per day. ${ }^{2}$ The annual thermal energy consumption was calculated similarly to the annual electricity consumption. 


\section{References}

1. Daily, G.C. Nature's Services: Societal Dependence on Natural Ecosystems, 1st ed.; Island Press: Washington, DC, USA, 1997; pp. 1-412.

2. Graymore, M.L.; Sipe, N.G.; Rickson, R.E. Sustaining Human Carrying Capacity: A tool for regional sustainability assessment. Ecol. Econ. 2010, 69, 459-468. [CrossRef]

3. Graymore, M.L.M.; Sipe, N.G.; Rickson, R.E. Regional sustainability: How useful are current tools of sustainability assessment at the regional scale? Ecol. Econ. 2008, 67, 362-372. [CrossRef]

4. Manning, R.E. Parks and Carrying Capacity: Commons Without Tragedy; Island Press: Washington, DC, USA, 2007; pp. 1-328.

5. Farrell, T. The Protected Area Visitor Impact Management (PAVIM) framework: A simplified process for making management decisions. J. Sustain. Tour. 2002, 10, 31-51. [CrossRef]

6. Saarinen, J. Traditions of sustainability in tourism studies. Ann. Tour. Res. 2006, 33, 1121-1140. [CrossRef]

7. Lawson, S.R.; Manning, R.E.; Valliere, W.A.; Wang, B. Proactive monitoring and adaptive management of social carrying capacity in Arches National Park: An application of computer simulation modeling. J. Environ. Manag. 2003, 68, 305-313. [CrossRef]

8. Needham, M.; Szuster, B.; Bell, C. Encounter norms, social carrying capacity indicators, and standards of quality at a marine protected area. Ocean. Coast. Manag. 2011, 54, 633-641. [CrossRef]

9. Prato, T. Modeling carrying capacity for national parks. Ecol. Econ. 2001, 39, 321-331. [CrossRef]

10. Prato, T. Fuzzy adaptive management of social and ecological carrying capacities for protected areas. J. Environ. Manag. 2009, 90, 2551-2557. [CrossRef]

11. Wagar, J.A. The Carrying Capacity of Wildlands for Recreation. Forest Sci. 1964, 10, 1-24.

12. Manning, R. Studies in Outdoor Recreation. Search and Research for Satisfaction, 3rd ed.; Cornallis Oregon State University Press: Oregon, OR, USA, 1999; pp. 1-448.

13. Stankey, G.; Cole, D.; Lucas, R.; Petersen, M.; Frissell, S.; Washburne, R. The Limits of Acceptable Change (LAC) System for Wilderness Planning. General Technical Report; USDA Forest Service, Intermountain Forest and Range Experiment Station: Ogden, UT, USA, 1985; p. 37.

14. Kuss, F.; Graefe, A.; Vaske, J. Visitor Impact Management, v.2 The Planning Framework; National Parks and Conservation Association: Washington, DC, USA, 1990.

15. National Park Service. Visitor Experience and Resource Protection (VERP) Framework. A Handbook for Planners and Managers; US Department of the Interior, National Park Service, Denver Service Center: Denver, CO, USA, 1997; pp. 1-108.

16. Payne, R.J.; Nilsen, P. Innovations and Challenges in the Management of Visitor Opportunities in Parks and Protected Area: Commemorating the Work of the Late Robert Graham. In Proceedings of the Workshop held at the University of Waterloo, Heritage Resources Center, Waterloo, ON, Canada, 1 December 1994.

17. Satta, A.; Klaric, Z.; Mangion, M.L.; Travic, A.S. Guide to Good Practice in Tourism Carrying Capacity Assessment, 1st ed.; Priority Actions Programme/Regional Activity Centre: Split, Croatia, 2003.

18. Hellenic Parliament. Law No. 3937/2011: Conservation of Biodiversity and Other Provisions; Hellenic Parliament: Athens, Greece, 2011.

19. Aktsoglou, D.; Gaidajis, G. Environmental Sustainability Assessment of Spatial Entities with Anthropogenic Activities-Evaluation of Existing Methods. Sustainability 2020, 12, 2680. [CrossRef]

20. Angelakoglou, K.; Gaidajis, G. A Conceptual Framework to Evaluate the Environmental Sustainability Performance of Mining Industrial Facilities. Sustainability 2020, 12, 2135. [CrossRef]

21. Liu, H. Comprehensive carrying capacity of the urban agglomeration in the Yangtze River Delta, China. Habitat Int. 2012, 36, 462-470. [CrossRef]

22. Rees, W.E. Urban ecosystems: The human dimension. Urb. Ecosyst. 1997, 1, 63-75. [CrossRef]

23. Cohen, J. How Many People Can. The Earth Support? W.W. Norton \& Company: New York, NY, USA, 1995.

24. Lane, M.C. The carrying capacity imperative: Assessing regional carrying capacity methodologies for sustainable land-use planning. In Proceedings of the 53rd Annual Meeting of the International Society for the Systems Sciences, Brisbane, Australia, 12-17 July 2009.

25. Peters, C.J.; Wilkins, J.L.; Fick, W.G. Testing a Complete-Diet Model for Estimating the Land Resource Requirements of Food Consumption and Agricultural Carrying Capacity-The New York State Example. Renew. Agric. Food Syst. 2007, 22, 145-153. [CrossRef] 
26. Fairlie, S. Can Britain Feed Itself? Land 2007, 4, 18-26.

27. Peters, C.J.; Wilkins, J.L.; Fick, W.G. Input and Output Data in Studying the Impact of Meat and Fat on the Land Resource Requirements of the Human Diet and Potential Carrying Capacity-The New York State Example. In CSS Research Series; Department of Crop and Soil Sciences: Ithaca, NY, USA, 2005; pp. 1-25.

28. Schroll, H.; Anderson, J.; Kjaergard, B. Carrying Capacity: An approach to local spatial planning in Indonesia. J. Transdiscipl. Environ. Stud. 2012, 11, 27-39.

29. Azapagic, A.; Perdan, S. Sustainable Development in Practice: Case Studies for Engineers and Scientists, 2nd ed.; John Wiley-BlackWeeel Ltd.: West Sussex, England, 2011.

30. Wackernagel, M.; Onisto, L.; Bello, P.; Linares, A.C.; Falfan, I.S.L.; Garcva, J.M.; Guerrero, A.I.S.; Guerrero, M.G.S. National natural capital accounting with the ecological footprint concept. Ecol. Econ. 1999, 29, 375-390.

31. Wackernagel, M.; Moran, D.; Wermer, P.; Goldfinger, S.; Deumling, D.; Murray, M. National Footprint and Biocapacity Accounds 2005-The Underlying Calculation Method, 2005 ed.; Global Footprint Network: Oakland, CA, USA, 2005.

32. Cucek, L.; Klemes, J.J.; Kravanja, Z. A review of Footprint analysis tool for monitoring impacts on sustainability. J. Clean. Prod. 2012, 34, 9-20. [CrossRef]

33. Haggar, S. Sustainable Industrial Design and Waste Management: Cradle-to-Grave for Sustainable Development, 1st ed.; Elsevier Academic Press: San Diego, CA, USA, 2007.

34. Borucke, M.; Moore, D.; Cranston, G.; Gracey, K.; Katsunori, I.; Larsoa, J.; Lazaru, E.; Moralea, J.C.; Wackernagea, M.; Galli, A. Accounting for demand and supply of the biosphere's regenerative capacity: The National Footprint Accounts' underlying methodology and framework. Ecol. Indic. 2013, 24, 518-533. [CrossRef]

35. Scotti, M.; Bondavalli, C.; Bodini, A. Ecological Footprint as a tool for local sustainability: The municipality of Piacenza (Italy) as a case study. Environ. Impact Assess. Rev. 2009, 29, 39-50. [CrossRef]

36. Ewing, B.; Goldfinger, S.; Wackernagel, M.; Stechbart, M.; Rizk, S.M.; Reed, A.; Kitzes, J. The Ecological Footprint Atlas 2008, 2008 ed.; Global Footprint Network: Oakland, CA, USA, 2008.

37. European Environment Agency. Available online: https://www.eea.europa.eu/publications/COR0-part1 (accessed on 10 November 2019).

38. Castellani, V.; Sala, S. Ecological footprint and life cycle assessment in the sustainability assessment of tourism activities. Ecol. Indic. 2012, 16, 135-147. [CrossRef]

39. Open Public Data. Land Cover of Greece in 2000, According to the Deliverables of the CORINE Program of the European Union. Available online: http://www.geodata.gov.gr/geodata/index.php?option=com_sobi2\& sobi2Task=sobi2Details\&catid=16\&sobi2Id=54\&Itemid (accessed on 10 December 2014).

40. Weber, C.; Matthews, S. Food-Miles and the Relative Climate Impacts of Food Choices in the United States. Environ. Sci. Technol. 2008, 42, 3508-3513. [CrossRef]

41. Balaras, C.; Gaglia, A.; Georgopoulou, E.; Mirasgedis, S.; Sarafidis, Y.; Lalas, D. European residential buildings and empirical assessment of the Hellenic building stock, energy consumption, emissions and potential energy savings. Build. Environ. 2007, 42, 1298-1314. [CrossRef]

42. Gaglia, A.; Balaras, C.; Mirasgedis, S.; Georgopoulou, E.; Sarafidis, Y.; Lalas, D. Empirical assessment of the Hellenic non-residential building stock, energy consumption, emissions and potential energy savings. Energ. Convers. Manag. 2007, 48, 1160-1175. [CrossRef]

(C) 2020 by the authors. Licensee MDPI, Basel, Switzerland. This article is an open access article distributed under the terms and conditions of the Creative Commons Attribution (CC BY) license (http://creativecommons.org/licenses/by/4.0/). 